\title{
MORTALITY AND INGROWTH PATTERN OF DIPTEROCARPS IN FOREST RECOVERY IN EAST KALIMANTAN
}

\author{
FARIDA H. SUSANTY, ENDANG SUHENDANG ${ }^{2}$ I NENGAH SURATI JAYA ${ }^{2}$ \\ and CECEP KUSMANA ${ }^{3}$ \\ ${ }^{1}$ Rercher on Dipterocarps Rerch Center, Samaninda 75119, Indonesia \\ ${ }^{2}$ Department of Forest Managemet, Institut Petanian Bogr(IPB), Bogr 16680, Indonesia \\ ${ }^{3}$ Department of Silvialture, Institut Petanian Bogr (IPB), Bogr 16680, Indonesia
}

Received 3 May 2013/ Accepted 24 November 2014

\begin{abstract}
ABST RACT
In primary and logged-over natural forest, the trees conditions such as tree structure, mortality and ingrowth rates will vary according to the species characteristic. Q uantitative management variables become very important to support yield regulation tools for achieving sustainable forest management. The study objective was to determine mortality and ingrowth rates to formulate biometric characteristic variability of D ipterocarps forest in logged-over forests based on time series data. The study site was located in Labanan, East Kalimantan Province. Permanent measurement plots within logged-over forest were located to represent three different logging techniques, i.e. a) reduced impact logging with diameter limit $50 \mathrm{~cm}$ (RIL 50); b) RIL 60; c) conventional logging; and d) primary forest as control. Total plot permanent area was about 48 haand was measured periodically every 2 years within 17 years after logging. For data analysis purpose, trees were divided into two major groups, i.e. D ipterocarps and non-Dipterocarps. Range of mortality rates for all species in logged-over forest were 2.5-29.3\% per ha per 2 years which was very close to primary forest at year-5 after logging. While range of ingrowth rate for all species in logged-over forest were 1.3-21.3\% per ha per 2 years which were higher than those for the primary forest within 17 years. The mortality and ingrowth rates fluctuation of D ipterocarps species group were different from those of non-Dipterocarps.
\end{abstract}

Keywords: D ipterocarps, ingrowth, logged-overforest, mortality

\section{INTRODUCTION}

Lowland tropical rain forest is a natural forest with trees having typical characteristics, harboring the greatest species diversity in the world (Whitmore 1990; Richards 1996) and having numerous variations of tree's dimensions (Prodan 1968). Lowland tropical rain forests in Southeast A sia are dominated by D ipterocarpaceae (Ashton 1982), therefore, it is often referred to as the Dipterocarp forests. Dipterocarp forest is a tropical rainforest inhabiting type A and type B climate types area, covering Sumatera, Kalimantan, Sulawesi, North Maluku and Papua with the highest layer of forest canopy filled with family Dipterocarpaceae, especially genus Shrea, Diptercarpus Dryobalanops and Hopee (Ashton 1982). D ipterocarp forest in West Malesia region

\footnotetext{
* Corresponding author : fhsusanty@gmail.com
}

is the most productive tropical forest types based on timber value (FAO 2001). In Indonesia, D ipterocarpaceae is the largest contributor (over $25 \%$ ) to commercial timber forests in decades, with volume of $50-100 \mathrm{~m}^{3}$ per ha, especially in Kalimantan (Sist etal. 2003).

In primary and logged-over natural forest, the stand conditions having differences in stand structure, species composition, tree density, canopy structure, mortality and ingrowth, will have varied growth rates depending on the tree age after logging (Silva \&al. 1995; Lewis \&al. 2004; Ishida $\&$ al. 2005). Recovery of a logged-over forest happens in a long period after logging (Smith \& Nichols 2005), which varies depending on deforestation rate and environmental carrying capacity (Muhdin \&al. 2008). Natural production forests in Indonesia have more than $50 \%$ of logged-over forests (Ditjen Planologi Kehutanan 2011). Therefore, it is very important to know 
about the variation of tree characteristics in a logged-over forest. Biology and ecology information of Dipterocarps is needed as scientific basis for developing effective forest management policies(Naito \&al. 2008).

Forest biometric characteristics is among quantitative approaches to study the properties or characteristics of forest trees in size (metric) for a specific biological dimension as the user identification by ratio and interval scale (Prodan 1968). Input variables to determine quantitative tools are mostly provided by classical forest inventories on plots (Vanclay 2003; GourletFleury $\&$ al. 2005). Most of the early biometric research are found in studies on plantations and temperate forests that do not have such complexity as tropical forests. The heterogeneity and complexity of obstacles occur in the forms of diversity and variation of conditions as well as limitations or lack of long term data observation. Average rate of mortality and its correlations to several reliable and measurable variables in size or site characteristics as input factors mostly determine the mortality model (Keister 1972; Hamilton \& Edwards 1976; Monserud 1976; Hamilton 1994; Monserud \& Sterba 1999; cited Flewelling \& Monserud 2002). According to Chertov eal. (2005), a new paradigm in achieving sustainable forest management requires prediction of effective growth forest tree dynamics involving aspects of ecological characteristics.

To achieve sustainable forest management, preparation of quantitative management tools such as yield regulation models becomes very important. Important variables needed to build the models are mortality and ingrowth rates of forest trees. This study aimed to determine mortality and ingrowth rates of Dipterocarps and non-D ipterocarps spesies groups for 17 years after being logged, which rates will be used to formulate biometric characteristics variability of D ipterocarp forest in logged-over forests based on time series data.

\section{MATERIALS AND METHODS}

\section{Study Site}

This study was carried out at Labanan research forest station $\left(1^{\circ} 49^{\prime}-2^{\circ} 10^{\prime} \mathrm{N}\right.$ and $116^{\circ} 7^{\prime}-117^{\circ} 27^{\prime}$ E) located in Berau Region, East Kalimantan Province. According to Schmidt and Ferguson climate classification (1951), the study site was within type B climate $(\mathrm{Q}=14.3-33.3 \%)$. Based on Koppen system classification the study site was within type AFA climate with many rainy days over in a year with mean annual precipitation about 1,800-3,000 mm/ year. The highest monthly mean precipitation happened in January $(242.5 \mathrm{~mm})$ and the lowest is in August $(90.9 \mathrm{~mm})$. Maximum temperature rate happens in September and November $\left(35^{\circ} \mathrm{C}\right)$ and the lowest was in February and August ( $21^{\circ} \mathrm{C}$ ), with average temperature of $26^{\circ} \mathrm{C}$. The study site was located at $500 \mathrm{~m}$ above sea level (asl) and it was a relatively hilly forest. Soil type in Labanan research forest station consisted of Ultisol (87.3\%), Entisol (10.7\%) and Incenptisol (2.0\%).

Labanan research forest station as a low land tropical forest is dominated by family Dipterocarpaceae, consisted of 7 genera i.e. A nisqutera, Cotydedium Diptexcarpus Drydbalangps Parashrea, Shrea and Vatica Besides family D ipterocarpaceae, other dominant genera are also present in Labanan research forest station such as Sapotacea, Meiacea, Maraceale Ebonaceae, Sapindaceand Leauminacee Among landscapes at the Labanan research forest station was a swamp forest dominated by Lophoptalum and Shareabalangeran(Saridan and Susanty 2005.

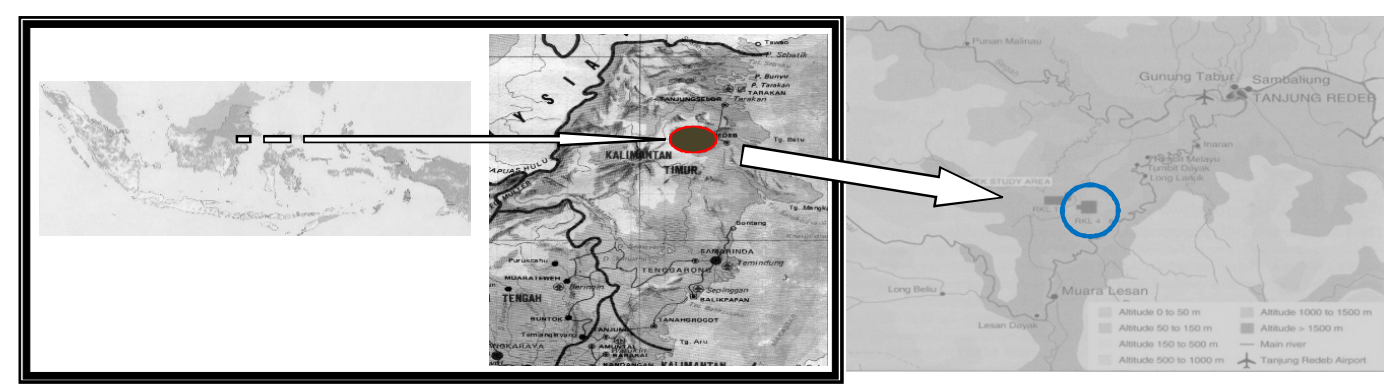

Figure 1. Study site-Labanan research forest station, Berau, East Kalimantan Province 


\section{Data Collecting}

Permanent plots were set up in the logged-over forest as well as in the primary forest. The size of each plot was 200x200 $\mathrm{m}$ (4ha) which was divided into 4 square subplots with size of $100 \times 100 \mathrm{~m}$ (1 ha). The permanent plots were built in 4 condition variations with total area of 48 ha. Measurements were carried out by census method for all species with limit diameter of $10 \mathrm{~cm}$ including number of trees, tree species, stem diameter (diameter at breast height or $20 \mathrm{~cm}$ above buttresses) and number of dead trees. Repeated measurements were performed every two years.

Reduced impact logging can be defined as logging technique to minimize environment impact on forest trees and soils (Dykstra 2008). This technique is needed to preserve ecological aspect of forest trees and to ensure sustainable yield of production forest in the future.

Data used in this study were data collected from 1990 to 2008. Treatments applied on research plots were as follows:

a) RIL 50: reduced impact logging techniques with limit diameter of $50 \mathrm{~cm}$, skid trail planning was based on contour maps and tree position as well as supervision of tree felling and skidding (3 plots).

b) RIL 60: reduced impact logging techniques with limit diameter of $60 \mathrm{~cm}$, skid trail planning was based on contour maps and tree position as well as supervision of tree felling and skidding (3 plots).

c) $\mathrm{CNV}$ : conventional logging techniques with limit diameter of $60 \mathrm{~cm}$, no skid trail planning, conducted without considering contour line maps or tree position, felling was done by loggers experiences ( 3 plots).

d) PF:primary forestascontrols (3 plots).

\section{Data Analysis}

Data organization was carried out using database software Microsoft Visual FoxPro 9.0, while data analysis was performed by using spreadsheet and SPSS 15.0. D ata were analyzed based on tree density and tree structure (stems per ha) as well as basal area ( $m^{2}$ per ha) with two major species groupings e.g. Dipterocarps and nonDipterocarps species. Calculations of mortality and ingrowth rates were performed every 2 years. Residual tree characteristics assessment was done by comparing variations in forest conditions by using different test mean values (t-test), analysis of variance (ANOVA) and regression analysis. Regression equation tested was linear equations, polynomials, exponential and logarithmic. Criteria used for selecting the best equation were based on the regression coefficient (r), determination coefficient $\left(\mathrm{R}^{2}\right)$ and the highest value of the smallest standard error (SE) (Steel \& Torrie 1995)

\section{RESULTS AND DISCUSSION}

\section{Tree Density}

The dynamics of logged-over forest within 17 years were represented by number of trees per hectare and basal area per hectare against tree fluctuations after-logging using different logging techniques (Fig. 2). Mean values of tree density at the initial conditions (pre-harvest) were compared using t-test and the results showed no significant differences in all study plots $\left(t_{\text {calc }}<t_{\text {tab }(0.05 ; 6)}\right)$. Fluctuations of tree density and basal area of logged-over forest would increase up to the initial conditions before logging (primary forest). Logged-over D ipterocarp forest recovery reached the conditions close to the primary forest at 9 years after-logging based on tree density and at 11 years after-logging based on basal area. According to Gourlet-Fleury \& al. (2005) and Kao and Iida (2006), tree density extremely increases at 5 to 7 years after-logging, which was explained by the increasing growth of open canopy in after-logging periods.

Range of tree density in the studied loggedover forest was 461-647 stems per ha with average value of 531 stems per ha. Sianturi and K anninen (2005) stated that at the period of 2 years afterlogging in Jambi forest, the tree density reached $90 \%$ compared with tree density at the same forestbeforelogging.

Tree density in a primary forest in Sangai, Central Kalimantan (478-738 stems per ha; average of 583 stems per ha) was similar to tree density in Labanan forest (Susanty 2006). This study results were also similar to the condition in eastern Amazon forest showing average tree density of $480 \pm 96.6$ stems per ha (Sist \& Ferreira 2007). While Gourlet-Fleury \& al. (2005) presented higher value of tree density for French $\mathrm{G}$ uianaforest (625 stems perha). 

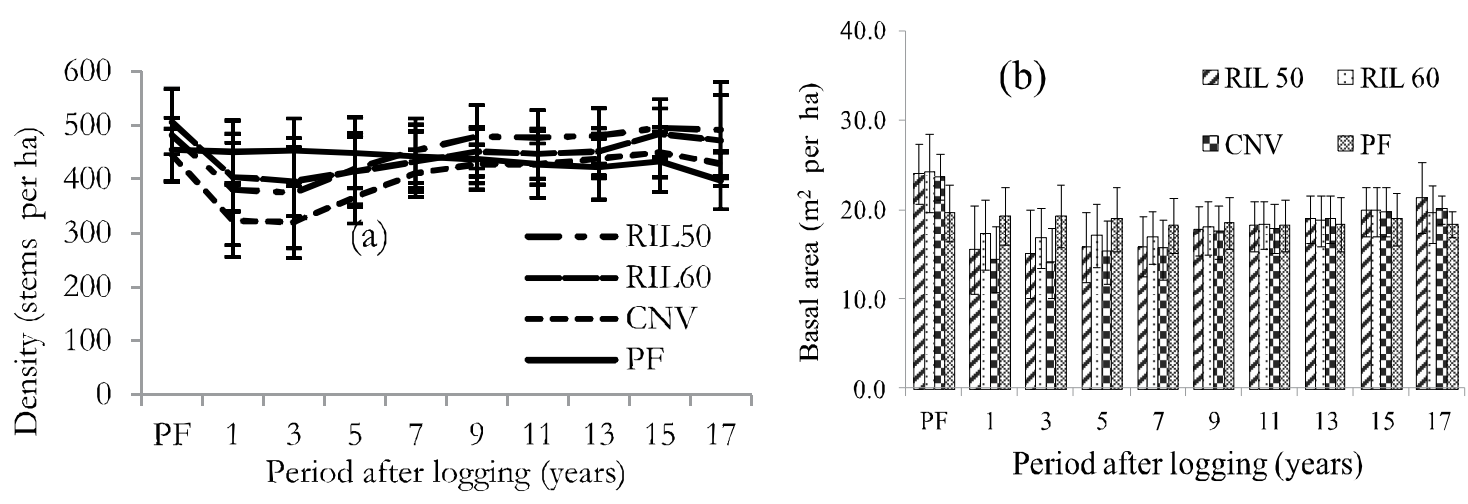

Figure 2. Forest trees for all species with different logging techniques based on (a) average tree density (stems per ha) and (b) average basal area ( $\mathrm{m}^{2}$ perha)

Range of basal area value in the studied logged-over forest was 19.35-31.84 $\mathrm{m}^{2}$ per ha. As comparisons, basal area value in a several years after-logging forest in Central Kalimantan ranged from 16.4 to $26.7 \mathrm{~m}^{2}$ per (Krisnawati 2001). A study conducted by Setiawan (2013) showed that basal area value in a logged-over forest in Muara Wahau, East Kalimantan ranged from 12.63 to $32.57 \mathrm{~m}^{2}$ per ha, while basal area value in a primary forest in Muara Wahau, East Kalimantan ranged from 27.80 to $32.57 \mathrm{~m}^{2}$ per ha. Basal area value in Amazon forest had average of $28 \pm 4 \mathrm{~m}^{2}$ per ha (Sist \& Ferreira 2007).

In logged-over forests, tree density was about 93-102\% and basal area were about $81.0-88.8 \%$ compared with initial condition or before logging condition. Based on this result, the recovery pattern of forest seemed to have positive trend with similar variations. The tree density afterlogging variable is important to know ecological sustainability (Sist \& al. 2003; Smith \& Nichols 2005; Muhdin 2012). This variable may indicate the level of all logged-over forest which have well recovered, with assumption no interference or disturbance, thereafter. Different recovery patterns of logged-over forest influenced ecological factor and forest tree condition. G rowth monitoring on a 24 ha permanent sample plots in silviculture experiments in Amazônia (1980-1989) indicated that even in the same block of concession area, forest recovery has different characteristics and patterns shown by fluctuations of tree dynamic (Silva \& al. 1995). Initial succession process in logged-over forests started from the end of logging operational, followed by growing process in a time series function.

\section{Mortality Rates}

The mortality level in different logging techniques is influenced by logging intensity based on number of trees and volume per hectare which were felled by logging. Logging intensity in RIL 50 had felled trees of $10.7 \pm 4.9$ stems per ha with volume of $96.8 \pm 66.5 \mathrm{~m}^{3}$ ha per; RIL 60 had felled trees of $7.0 \pm 3.0$ stems per ha with volume of $56.5 \pm 23.3 \mathrm{~m}^{3}$ per ha and CNV had felled trees of $10.1 \pm 4.2$ stems per ha with volume of 107.2 $\pm 59.6 \mathrm{~m}^{3}$ per ha (Sist \& Bertault 1998). These results indicated that logging intensity had a tendency to increase from RIL 60, RIL 50 and $\mathrm{CNV}$ logging techniques, respectively. In the logged-over forest, the mortality rates for all species ranged from 2.5 to $29.3 \%$ per ha per 2 years (Table 1). The highest mortality rates occurred in year- 1 and year-3 after logging then declined or was similar to mortality rates at the primary forest in year- 5 after logging. The mortality rates in this study were higher than those in some studies; for example mortality rate in year-2 after logging in East Kalimantan forest was 2.5\% per year (Primack \& al. 1985; NguyenThe $\&$ al. 1998); mortality rate in a logged-over forest in Papua N ew G uinea was 2.5\% per ha per year (Mex 2005); mortality rate in a mixed Dipterocarp forests in Asia was 1.5\% per year (Nguyen-The \& al. 1998). Compared to other forest types, Dipterocarp forest has lower mortality rate than that of peat swamp forest which was $6.13 \%$ per year and of heath forests which was $4.26 \%$ per year (Nishimua eal. 2006).

Mortality rates in forest with different logging techniques indicated higher logging intensity for both Dipterocarps and non-D ipterocarps (Fig. 3). 
Table 1. Tree mortality rates (\% per ha per 2 years) for all species

\begin{tabular}{|c|c|c|c|c|c|c|c|c|c|c|}
\hline \multirow{2}{*}{\multicolumn{2}{|c|}{$\begin{array}{c}\text { Forest } \\
\text { Condition }\end{array}$}} & PAL1 & PAL3 & PAL 5 & PAL7 & PAL9 & PAL 11 & PAL13 & PAL 15 & PAL17 \\
\hline & & \multicolumn{9}{|c|}{ (\% per ha per 2 years) } \\
\hline \multirow{2}{*}{ RIL50 } & Mean & 23.7 & 10.9 & 4.3 & 5.8 & 3.0 & 2.9 & 2.7 & 3.4 & 3.3 \\
\hline & SD & 10.6 & 6.2 & 1.4 & 1.2 & 0.7 & 1.1 & 1.1 & 1.7 & 1.5 \\
\hline \multirow{2}{*}{ RIL60 } & Mean & 22.3 & 8.3 & 4.4 & 5.5 & 3.3 & 2.5 & 2.5 & 2.5 & 3.5 \\
\hline & SD & 8.1 & 3.5 & 1.1 & 1.3 & 0.9 & 0.8 & 1.1 & 1.3 & 2.0 \\
\hline \multirow[t]{3}{*}{ CNV } & Mean & 29.3 & 12.8 & 2.8 & 6.8 & 3.3 & 3.6 & 2.8 & 2.9 & 4.3 \\
\hline & SD & 9.2 & 8.0 & 1.3 & 2.3 & 0.9 & 2.1 & 1.0 & 1.9 & 0.4 \\
\hline & & $\mathrm{P} 1$ & P3 & $\mathrm{P} 5$ & P7 & P9 & $\mathrm{P} 11$ & $\mathrm{P} 13$ & $\mathrm{P} 15$ & $\mathrm{P} 17$ \\
\hline \multirow[t]{2}{*}{$\mathrm{PF}$} & Mean & 2.9 & 3.2 & 4.7 & 6.0 & 3.2 & 3.4 & 2.7 & 2.0 & 3.2 \\
\hline & SD & 1.0 & 1.3 & 5.1 & 1.8 & 1.2 & 1.5 & 1.5 & 1.4 & 2.0 \\
\hline
\end{tabular}

Notes $:$ PAL $=$ period after logging (years)

$\mathrm{SD}=$ Standard deviation

$\mathrm{P}=$ monitoring period (years)
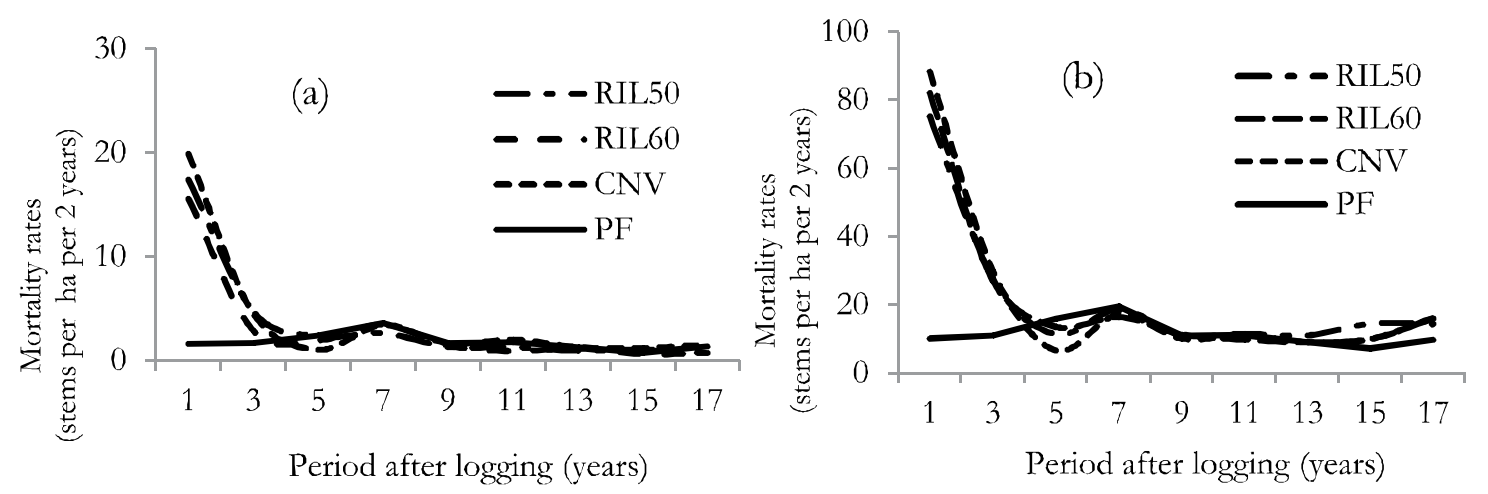

Figure 3. Mortality rates (stems per ha per 2 years) of trees with different logging techniques for species group (a) Dipterocarpsand (b) non-D ipterocarps

Non-Dipterocarps species have a tendency to have higher mortality rate than Dipterocarps. Mortality rate for both Dipterocarps and nonDipterocarps in primary forest ranged from 2.0 to $6.0 \%$ per ha per 2 years with average of $3.29 \%$ per ha per 2 years. The increasing logging intensity was negatively correlated with stem densities, species abundance and biodiversity, where prior changes in the logged-over forest for the first 5-10 years after logging were gradually occurred in successive samples (K ariuki $\notin$ al. 2006). The mortality rates of trees in aforest is relatively high within 7 years, indicating that damaging effects of logging would permanently influence trees, either directly or indirectly. In other words, within 7 years after logging, the remaining trees will begin to recover.

Fluctuations of mortality rate within 17 years after logging indicated that the mortality rates decreased over years for both Dipterocarps and
non-Dipterocarps. A theoretical frame for ingrowth limitations, climatic variation or many factors became the constraints to predict treelevel change (Harcombe \& al. 2002). Several variables causing differences of mortality rates were logging intensity, initial structure and dominant species composition. The mortality degree is different for every tree's stage in the forests.

\section{Ingrowth Rates}

Ingrowth rates in logged-over forest have the same tendency with mortality rates that correlate with level of logging intensity (Table 2). In this case, conventional logging technique can still control the total felled trees to only cut down trees having limit diameter of $60 \mathrm{~cm}$. The ingrowth rates in logged-over forest (1.3-21.3\% per ha per2 years) were higher than those in primary forest (0.6- $4.7 \%$ per ha per 2 years). The highest 
ingrowth rate for all species occurred at year- 5 to year-7 (Table 2). After logging, the ingrowth rates increased substantially during the first 5 years. D uring the next five years, there was a sharp decrease. Hardiansyah \& al. (2005) stated that at year-1 after logging in Jambi, ingrowth rate was $0.19-2.89 \%$ per year with average $2.1 \%$ per year. Meanwhile, in Papua New Guinea Mex (2005) stated that at year-13 after logging the trees had smaller ingrowth rate with mean of 41 stems per ha. In the primary forest, ingrowth rate fluctuation were relatively low i.e. $2.0-4.7 \%$ per ha per 2 years with average of $2.5 \%$ per ha per 2 years. Fluctuations of ingrowth rates for Dipterocarps and non-Dipterocarps species in logged-over forest with different logging techniques had different patterns (Fig. 4). In this study 68 tree families had been identified (Appendix 1), in which there were 8 genera of Dipterocarps (Appendix 2) namely Anisqutera, Cotylddaium Dipterocarpus Drydbalanops Hopee, Parashrea, Shree, and Vatica consisted of 92 species. Non-Dipterocarpaceae trees dominating the logged-over forest were especially pioneer species such as Macaranga sp. This result was similar to the research results in Brazilian A mazon forest which showed that the ingrowth rate increased in the first 8 years after logging provided there were more light in the understorey which stimulated ingrowth (Silva $\&$ al. 1995). Ingrowth can soar through the canopy opening after logging provided there were more growing space and ingrowth would decrease in line with the competition among trees (Gourlet-Fleury \&al. 2005). Logged-over forests would have good recovery with high growth rate at year-3 after logging (Kao \& Iida 2006). The first highest ingrowth rate occurred in year-7 indicating high growth regeneration which in line with the beginning of mortality rate decline in year-7. The second highest ingrowth rate occurred in year-15 which might be caused by recovery process of forest trees after being logged-over.

Table 2. Tree ingrowth rates (\% per ha per 2 years) for all species

\begin{tabular}{|c|c|c|c|c|c|c|c|c|c|c|}
\hline \multirow{2}{*}{\multicolumn{2}{|c|}{$\begin{array}{c}\text { Forest } \\
\text { Condition }\end{array}$}} & PAL1 & PAL 3 & PAL5 & PAL 7 & PAL9 & PAL11 & PAL 13 & PAL 15 & PAL17 \\
\hline & & \multicolumn{9}{|c|}{ (\% per ha per 2 years $\left.{ }^{1}\right)$} \\
\hline \multirow[t]{2}{*}{ RIL50 } & Mean & 1.8 & 9.0 & 21.3 & 14.5 & 8.8 & 2.8 & 3.4 & 6.5 & 0.6 \\
\hline & $\mathrm{SD}$ & 0.6 & 4.9 & 25.3 & 8.9 & 4.4 & 2.4 & 1.7 & 2.7 & 0.2 \\
\hline \multirow[t]{2}{*}{ RIL60 } & Mean & 2.1 & 6.3 & 9.0 & 10.5 & 7.9 & 1.6 & 3.5 & 9.8 & 0.7 \\
\hline & SD & 1.0 & 2.3 & 2.3 & 3.3 & 3.8 & 1.0 & 1.4 & 5.7 & 0.1 \\
\hline \multirow[t]{3}{*}{ CNV } & Mean & 1.3 & 12.7 & 19.1 & 19.6 & 7.8 & 3.5 & 5.2 & 5.4 & 0.7 \\
\hline & SD & 0.6 & 8.5 & 13.4 & 8.2 & 4.8 & 1.2 & 2.6 & 1.9 & 0.2 \\
\hline & & $\mathrm{P} 1$ & P3 & P5 & $\mathrm{P7}$ & $\mathrm{P9}$ & $\mathrm{P} 11$ & $\mathrm{P} 13$ & $\mathrm{P} 15$ & $\mathrm{P} 17$ \\
\hline \multirow[t]{2}{*}{$\mathrm{PF}$} & Mean & 2.1 & 3.8 & 3.7 & 4.7 & 2.0 & 1.1 & 1.6 & 4.5 & 0.7 \\
\hline & SD & 1.0 & 1.9 & 1.9 & 2.2 & 1.1 & 1.1 & 0.9 & 2.7 & 0.6 \\
\hline
\end{tabular}

Notes : PAL $=$ period after logging (years)

$\mathrm{SD}=$ Standard deviation

$\mathrm{P}=$ monitoring period (years)
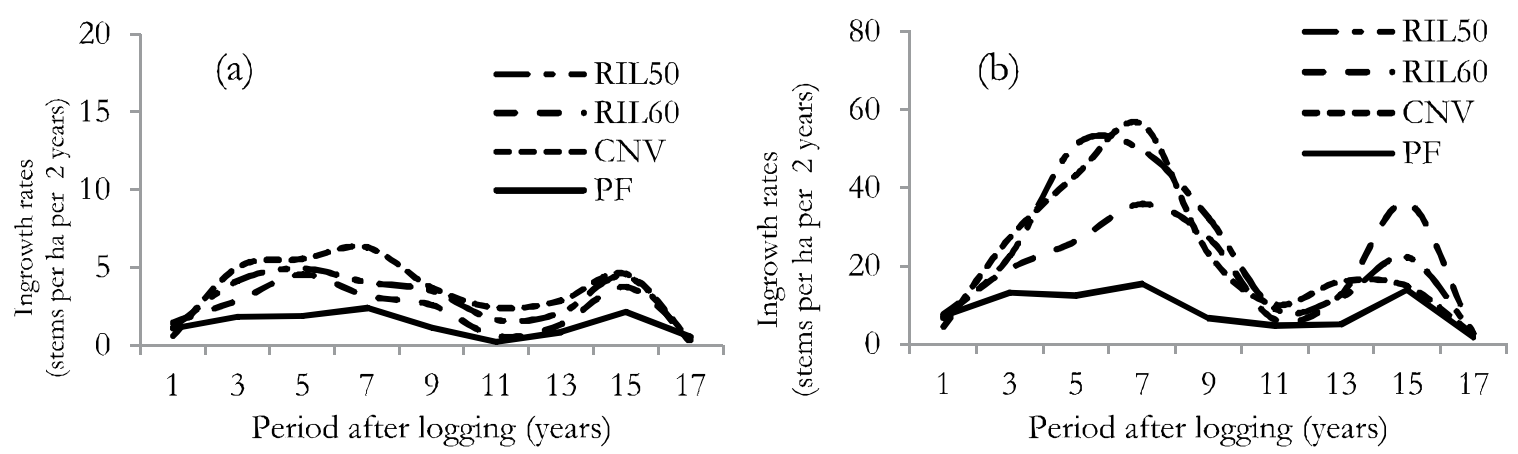

Figure4. Ingrowth rates (stems per ha per 2 years) of trees with different logging techniques for species group (a) Dipterocarpsand (b) non-D ipterocarps 
Canopy gap occurred in a logged-over forest can function as a catalyst for tree ingrowth until certain condition. This phenomenon would then decrease due to competition in population (Gourlet-Fleury \& al. 2005; Kao \& Iida 2006), which would explain why natural ingrowth formed in the period of 11-17 years in the forest recovery. Different species group will be affected variably to competition for light based on respective tolerable range (Harcombe $\boldsymbol{\epsilon}$ al. 2002). Research on forest tree in Peninsular Malaysia showed variations in regenerated tree by class diameter of trees in the logged-over forest area (Seng tal. 2004).

\section{Period after Logging to Mortality and Ingrowth Pattern}

Results of analysis of variance (ANOVA) showed that different harvesting techniques had no significant effect on mortality rate and ingrowth rate for all species. However, descriptively, the mortality and ingrowth rates were higher at year-1 and year-3 after logging (Tables 1 and 2). From this study it was indicated that RIL 50 seemed to be the best technique to increase ingrowth rate, but RIL 60 was the selected technique to decrease the mortality rate after logging.

Regression equations were developed to show relationship between after-logging period to mortality and ingrowth rates for each species group (Table 3). These equations showed that after-logging period correlated with mortality rate in logged-over forest for both D ipterocarps and non-D ipterocarps. Recovery period after logging will affect the level of mortality and ingrowth rates for Dipterocarps, non-D ipterocarps and all species groups (Fig. 4). All species group in logged-over forest had polynomial regression pattern for mortality and ingrowth rates, but ingrowth rates on primary forest had negative exponential pattern.

High mortality rate was shown to happen in Dipterocarps in early years of logging and seemed to be caused by Dipterocarps being a major commencial species. Meanwhile, high mortality rate for non-Dipterocarps seemed to be due to forest area clearing related to skidding trails and logging yard as well as to logging operation.

Mortality rates for Dipterocarps and nonD ipterocarps as either direct or indirect effect of logging was continued until the third year. Ingrowth rates of non-Dipterocarps species group was higher than that of Dipterocarps. This was correlated with general growth or increment characteristics of total tree basal area increment of non-Dipterocarps which was higher than that of Dipterocarps species groups (Silva \& al. 2002; Susanty \& Suhendang 2013).

Table3. Regression equations between after-logging period (x) to mortality rates (M) and ingrowth rates (I) for D iptero carps (D), non-D ipterocarps (ND) and all species

\begin{tabular}{lllrrr}
\hline $\begin{array}{l}\text { Species } \\
\text { grouping }\end{array}$ & & Regression equation & $\mathrm{r}$ & $\mathrm{R}^{2}$ & $\mathrm{SE}$ \\
\hline $\mathrm{D}$ & LOF & $\mathrm{y}(\mathrm{M})=-0.039 \mathrm{x}^{3}+1.295 \mathrm{x}^{2}-13.177 \mathrm{x}+43.501$ & 0.8955 & 0.8020 & 4.855 \\
& & $\mathrm{y}(\mathrm{I})=0.011 \mathrm{x}^{3}-0.3676 \mathrm{x}^{2}+3.2295 \mathrm{x}+0.2946$ & 0.5326 & 0.2837 & 3.552 \\
& $\mathrm{PF}$ & $\mathrm{y}(\mathrm{M})=0.0073 \mathrm{x}^{3}-0.2272 \mathrm{x}^{2}+1.8366 \mathrm{x}+0.8951$ & 0.6448 & 0.4158 & 1.577 \\
& & $\mathrm{y}(\mathrm{I})=5.107 \mathrm{e}^{-0.133 \mathrm{x}}$ & 0.4106 & 0.1686 & 0.371 \\
\hline ND & LOF & $\mathrm{y}(\mathrm{M})=-0.0779 \mathrm{x}^{3}+2.6842 \mathrm{x}^{2}-28.4 \mathrm{x}+101.3$ & 0.9071 & 0.8229 & 9.985 \\
& & $\mathrm{y}(\mathrm{I})=0.0667 \mathrm{x}^{3}-2.1667 \mathrm{x}^{2}+18.792 \mathrm{x}-11.094$ & 0.6317 & 0.3990 & 14.765 \\
& PF & $\mathrm{y}(\mathrm{M})=0.0196 \mathrm{x}^{3}-0.5982 \mathrm{x}^{2}+4.8012 \mathrm{x}+4.3734$ & 0.6118 & 0.3743 & 4.142 \\
& & $\mathrm{y}(\mathrm{I})=13.873 \mathrm{e}^{-0.082 x}$ & 0.4900 & 0.2401 & 0.339 \\
\hline All species & LOF & $\mathrm{y}(\mathrm{M})=-0.1174 \mathrm{x}^{3}+3.9793 \mathrm{x}^{2}-41.577 \mathrm{x}+144.81$ & 0.9160 & 0.8391 & 13.686 \\
& & $\mathrm{y}(\mathrm{I})=0.0778 \mathrm{x}^{3}-2.5343 \mathrm{x}^{2}+22.022 \mathrm{x}-10.799$ & 0.6363 & 0.4049 & 17.288 \\
& PF & $\mathrm{y}(\mathrm{M})=0.0269 \mathrm{x}^{3}-0.8254 \mathrm{x}^{2}+6.6378 \mathrm{x}+5.2685$ & 0.6375 & 0.4064 & 5.474 \\
& & $\mathrm{y}(\mathrm{I})=17.636 \mathrm{e}^{-0.078 \mathrm{x}}$ & 0.4775 & 0.2280 & 0.3359 \\
\hline
\end{tabular}

Notes: LOF : Logged-over forest; PF : Primary Forest; $\mathrm{x}$ : after-logging period (years); $\mathrm{y}(\mathrm{M})$ : Mortality rates (stems per haper 2 years); $\mathrm{y}$ (I): Ingrowth rates (stems per haper 2 years) 

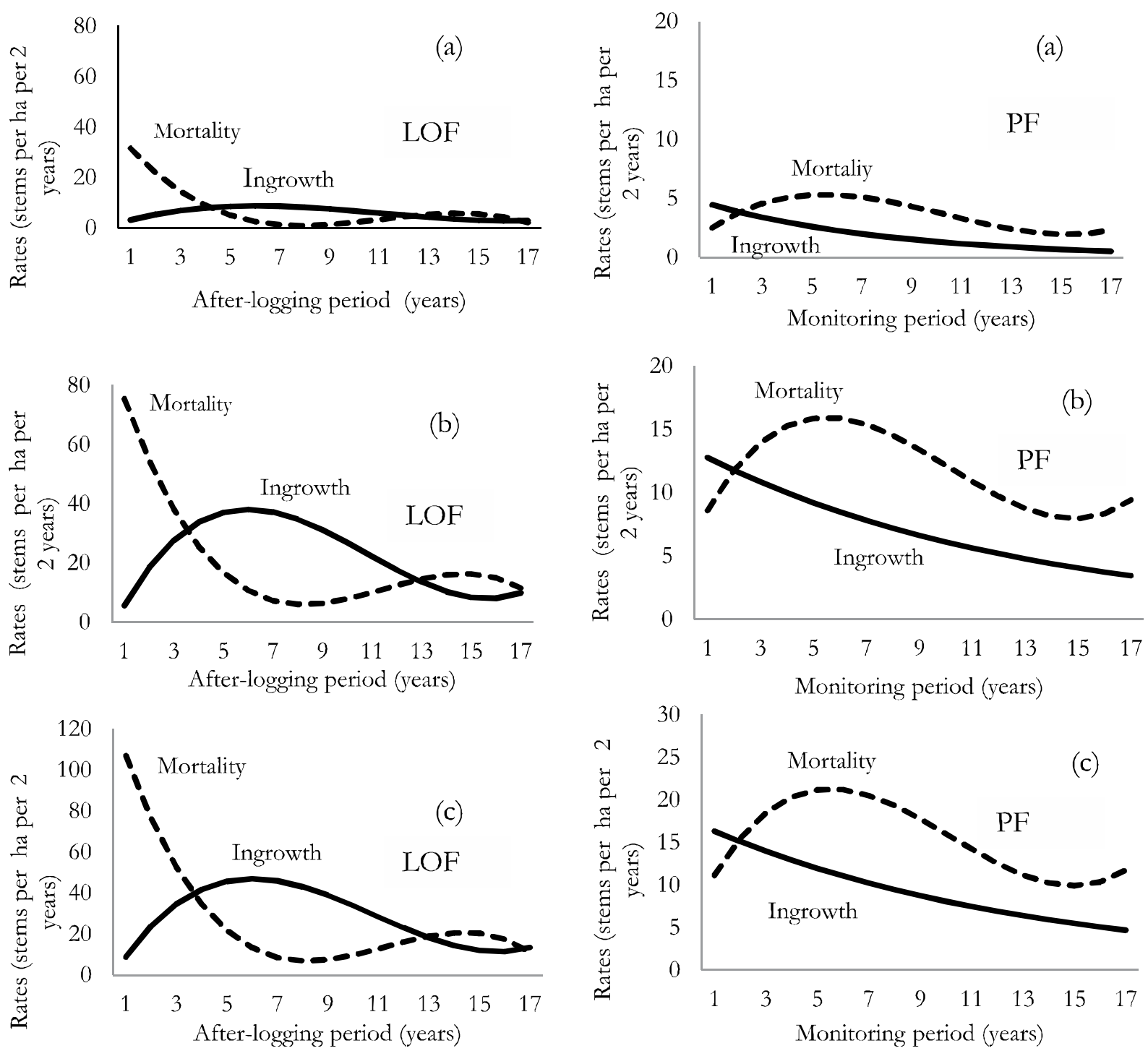

Figure5. Patterns of mortality and ingrowth rates (stems per ha per 2 years) on logged-over forest (LOF) and primary forest (PF) for species groups (a) D ipterocarps; (b) non-D ipterocarps; (c) all species

Results of regression analysis (Table 3; Fig. 5) showed that after-logging period was significantly correlated to mortality rates for both D ipterocarps and non-Dipterocarps. The function of recovery time after logging would reduce mortality rates from logging effect into natural mortality rates. Ingrowth rates after logging for both Dipterocarps and nonDipterocarps could not be explained only from recovery time after logging. Opportunity for seedlings and saplings to grow is influenced by biocharacteristics of each species and by distribution pattern (Husch $\&$ al. 2003; Adam \& Kolbs 2005; Gersonde \& O'Hara 2005). Natural characteristics of mortality and ingrowth rates shown by primary forest conditions indicated that mortality rate tended to be higher than ingrowth ratewithin the 17 years of measurements for both D ipterocarps and non-Dipterocarps. In natural forest, growth will increase the dimension of individual trees while reducing the number of trees due to competition of growing space.

Results from this research provided the first quantitative information for management planning in Labanan forest. To achieve higher ingrowth rate and minimize mortality rate until year-3 after-logging, the Reduced Impact Logging technique (RIL 50 and RIL 60) was better than conventional logging technique. These data serve as basic information needed to start forest management planning and provide useful guide for choosing suitable planning system. This study highlighted the need to consider silviculture treatment to stimulate 
growth rates in forest areas, especially to increase wood production. The methods described in this study can be enhanced to involve a more detail species grouping for increasing model accuracy and to accommodate high species diversity (Phillips \& al. 2002; Valle \& al. 2006). In Dipterocarp forest, valuation of tree recovery could be assessed by tree structure model, mortality rate and ingrowth rate, involving species characteristic by species grouping.

\section{CONCLUSIONS}

Residual trees in Dipterocarp forest in year-17 after-logging had been well recovered based on density and basal area value that reached more than $85 \%$ close to the initial condition. Mortality rates in logged-over forest would be similar to that in the primary forest at year-7 after-logging, while ingrowth rate in logged-over forest would be similar to that in the primary forest at year- 17 after- logging. Fluctuations in mortality and ingrowth rates in logged-over forest reached equilibrium conditions at year-7 after-logging. In the subsequent years, ingrowth rate was higher than mortality rate. Fluctuations of mortality and ingrowth rates in the primary forests were relatively low. Recovery period for trees in logged-over forest had an important effect to decrease mortality rates for both Dipterocarps and non-Dipterocarps. Different types of logging techniques (RIL 50, RIL 60 and conventional logging) with variations in logging intensity 7-14 stems per hectare did not have significant influence on recovery of density and basal area value, as well as on mortality and ingrowth rates. The Reduced Impact Logging technique was better than conventional logging technique to achieve higher ingrowth rate and minimize mortality rate until year-3 after-logging. Q uantitative dimensions of forest trees at 17 years after logging will be close with the primary forests, but still dominated by the non-Dipterocarps species.

\section{ACKN OWLEDGEMENTS}

The authors thanked the Forest Research and D evelopment Agency (FORDA) and Dipterocarps Research Center (DIREC) for permitting the use of data measurement of permanent sample plots in the Labanan forest station.

\section{REFERENCES}

Adams HD, Kolbs TE. 2005. Tree growth response to drought and temperature in a mountain landscape in Northern Arizona, USA.J Biogeogr 32:1629-40.

Ashton PS. 1982. Dipterocarpaceae. Flora Malesiana The Netherlands 1(9): 237-552.

Chertov O, Komarov A, Mikhailov A, Andrienko G, Andrienko N, Gatalsky P. 2005. G eovisualization of forest simulation modeling results: A case study of carbon sequestration and biodiversity. Comput Electron Agr 49: 175-91.

Davis LS, Johnson KN, Bettinger PS, Howard TE. 2001. Forest Management: ToSustain Edogjal, Econmicand Soial Value Fourth Edition. New York (US): McGraw-Hill.

Direktorat Jenderal Planologi Kehutanan, Kementerian Kehutanan. 2011. Data dan Infomas Pemanfaatan Hutan Tahun 2011. Jakarta(ID ): D irektorat Jenderal Planologi Kehutanan, Kementerian Kehutanan.

Dykstra DP. 2002. Reduced impact logging : concepts and issue. In: Enters T, D urst PB, Applegate GB, Kho PCS, Man G, editor. A pplyingRedured Impad Logging to AdvameSustainableForest Mamagemet. Rome(IT): FAO.p 23-40.

Food and Agricultural Organization of the United Nations. 2001. Stateof TheWorldForest Rome.

Flewelling JW, Monserud RA. 2002. Comparing methods for modelling tree mortality. In: $2^{\text {nd }}$ Forest Vegetation Simulator Conference. Proceedings: 2002 Feb 12-14; FortCollins(US). p 168-77.

G ersonde RF, O'Hara KL. 2005. Comparative tree growth efficiency in Sierra Nevada mixed-conifer forests. Forest EcolManag 219:95-108.

G ourlet-Fleury S, Cornu G, Jesel S, D essard H, Jourget JG, Blanc L, Picard N. 2005. Using models to predict recovery and assess tree species vulnerability in logged tropical forests : a case study from French Guiana. ForestEcol Manag 209:69-86.

Harcombe PA, Bill CJ, Fulton M, G litzenstein JS, Marks PL, Elsik IS. 2002. Stand dynamics over 18 Years in a southern mixed hardwood forest, Texas, USA. J Ecol 90:947-57.

Hardiansyah G, Hardjanto T, Mulyana M. 2005. A brief note on TPTJ (Modified Indonesia Selective Cutting System) from experience of PT. Sari Bumi Kusuma (PT SBK) timber concessionaire. In: International Workshop on Promoting Permanent Sample Plots in Asia and The Pacific Region. Proceedings: 2005 August 3-5; Bogor(ID): Center for International Forestry Research (CIFOR). p 23-31. 
Husch B, Beers TW, Kershaw Jr JA. 2003. Forest Mensuration Fourth E dition. New Jersey (US): John Wiley \& Sons Inc.

Ishida H, Hattori T, TakedaY. 2005. Comparison of species composition and richness between primary and secondary lucidophyllous forests in two altitudinal zones of Tsushima Island, Japan. Forest Ecol Manag 213: 273-87.

Kao D, Iida S. 2006. Structural characteristics of logged evergreen forests in Preah V ihear, Cambodia, 3years afterlogging. ForestEcol Manag 225: 62-73.

Kariuki M, Robert MK, Smith RGB, Johnson GW, Vanclay JK. 2006. Regeneration changes in tree species abundance, diversity and structure in logged and unlogged subtropical rainforest over a 36-year period. ForestEcol Manag 236:162-76.

Krisnawati H. 2001. Pengaturan hasil hutan tidak seumur dengan pendekatan dinamika struktur tegakan (kasus hutan alam bekas tebangan). tesis Bogor(ID): Institut Pertanian Bogor.

Lewis SL, Oliver LP, D ouglas S, Barbara V, Timothy RB, Sandra B, Andrew WG, Niro H, David WH, William FL, Jean L, Yadvinder M, Abel M, Pency NV, Bonaventure S, Nur SMN, John W, Terborgh, Rodolfo VM. 2004. Tropical forest tree mortality, recruitment and turnover rates: calculation, interpretation and comparison when census intervalsvary. JEcol 92: 929-44.

Mex PM. 2005. Progress on the studies of growth of logged over natural forest in Papua N ew G uinea. In: International Workshop on Promoting Permanent Sample Plots in Asia and The Pacific Region. Proceedings: 2005 Aug 3-5; Bogor(ID ): Center for International Forestry Research (CIFOR). p 70-86.

Muhdin, Suhendang E, Wahjono D, Purnomo H, Istomo, Simangunsong BCH. 2008. Keragaman struktur tegakan hutan alam sekunder.J Man Hut Trop 16(2): 81-7.

Muhdin. 2012. Dinamika struktur tegakan hutan tidak seumur untuk pengaturan hasil hutan kayu berdasarkan jumlah pohon (kasus pada areal bekas tebangan hutan alam hujan tropika dataran rendah tanah kering di Kalimantan). disetas. Bogor (ID): Institut Pertanian Bogor.

Naito Y, Kanzaki M, Iwata H, Obayashi K, Lee SL, Muhammad N, Okuda T, Tsumura Y. 2008. Density-dependent selfing and its effects on seed performance in a tropical canopy tree species, Shorea aaminata (D ipterocarpaceae). Forest Ecol Manag 256: 375-83.

Nguyen-The, N, Favrichon V, Sist P, Houde L, Bertault JG, Fauvet N. 1998. Growth and mortality pattern before and after logging. In: Bertault JG, Kadir K, editor. Silviailtural Reserch in A Lowand Mixed Dipterocarp Fonest of East Kalimantan The Contribution of STREK Project. Jakarta(ID): CIRAD-Forêt-FORDA-PT InhutaniI.p181-84.
Nishimua TB, Suzuki E, Kohyama T, Tsuyuzaki S. 2006. Mortality and growth of trees in peat-swamp and heath forests in Central Kalimantan after severe drought. PlantEcol 188: 165-77.

Phillips PD, Yasman I, Brash TE, van Gardingen PR. 2002. Grouping tree species for analysis of forest data in Kalimantan (Indonesian Borneo). Forest Ecol Manag 157:205-16.

Primack RB, Ashton P, Chai P, Lee HS. 1985. Growth rates and population structure of Moraceae trees in Sarawak, East Malaysia. Ecol 66:577-88.

Prodan M. 1968. Forest Biomerics Sabine H. Gardiner, translator. Oxford(UK): Pergamon Press.

Richards PW. 1996. The Tropical Rain Forest: Seeond eelition Cambridge(UK): Cambridge University Press.

Saridan A, Susanty FH. 2005. Pld STREK : Tkmik Silvikultur untuk Pemliaan Hutan Bkas Tdæancan di Kalimantan Timur. Samarinda(ID): D epartemen Kehutanan. Balai Penelitian dan Pengembangan Kehutanan K alimantan.

SchmidtFH, Ferguson JHA. 1951. Rainfall TypeBasedonWe and Dry Period Ratio for Indonesia with Westem New Guime Jakarta(ID): Kementerian Perhubungan. Jawatan Meteorologi dan G eofisika.

Seng HW, Wickneswari R, Shukor MN, Mahani MC. 2004. The effects of the timing and method of logging on forest structure in Peninsular Malaysia. Forest Ecol Manag 203:209-8.

Setiawan A. 2013. Keragaan struktur tegakan dan kepadatan tanah pada tegakan tinggal di hutan alam produksi. disetas. Bogor(ID ): InstitutPertanian Bogor.

Sianturi P, Kanninen M. 2005. Indonesian natural tropical forests would not be sustainable under the current silvicultural guidelines - TPTI (a simulation study). In: International Workshop on Promoting Permanent Sample Plots in Asia and The Pacific Region. Proceedings: 2005 August 3-5; Bogor(ID): Center for International Forestry Research (CIFOR). p32-46.

Simon H. 2007. Metode Inventare Hutan Yogyakarta (ID): Penerbit Pustaka Pelajar.

SilvaJNM, deCarvalhoa JOP, Lopes JCA, de Almeidaa BF, Costa D HM, de Oliveira LC, Vanclay JK, Skovsgaardd JP. 1995. Growth and yield of a tropical rain forest in the Brazilian Amazon 13 years after logging. ForestE col Manag 71:267-74.

Silva RP, dos SantosJ, Tribuzy ES, Chambers JQ , Nakamura S, Higuchi N. 2002. Diameter increment and growth patterns for individual tree growing in Central Amazon, Brazil. Forest Ecol Manag 166:295-301.

Sist P, Bertault JG. 1998. Reduced impact logging experiments: impact of harvesting intensities and logging techniques on stand damage. In: Bertault JG, Kadir K, editor. Silkialtural ReserchinaLonkand 
Mixed Dipterocarp Foret of East Kalimantan The Contribution of STREK Project. Jakarta(ID): CIRAD-Forêt-FORDA-PT InhutaniI.p 139-61.

Sist P, Fimbel R, Sheil D, Nasi R, Chevallier MH. 2003. Towards sustainable management of mixed Dipterocarp forests of South-East Asia: moving beyond minimum diameter cutting limits. Environ Conserv 30(4):364-74.

Sist P, Ferreira FN. 2007. Sustainability of reduced-impact logging in the Eastern Amazon. Forest E col Manag 243:199-209.

Smith RGB, Nichols JD. 2005. Patterns of basal area increment, mortality and recruitment were related to logging intensity in subtropical rainforest in Australia over 35 years. Forest Ecol Manag 218: 31928.

Steel RGD, Torrie JH. 1995. Pinsip dan Prosedur Statistika: SuatuPendkatan Biomerik. Sumantri B, penerjemah. Jakarta (ID): PT Gramedia Pustaka Utama. Terjemahan dari: Principles and Procedures of Statistics. Edisi ke-2.
Susanty FH, Suhendang E. 2013. Riap individu dan tegakan periodik hutan Dipterocarpaceae setelah penebangan. In: Ngatiman, Wahyudi A, editor. Restorasi ekosistem Dipterokarpa dalam rangka peningkatan produktivitas hutan. Prosiding: 2013 O ktober 22; Samarinda (ID): Kementerian Kehutanan. Balai Besar Penelitian Dipterokarpa. p156-67.

Vanclay JK. 2003. G rowth modelling and yield prediction for sustainable forest management. The Malaysian Forester66(1):58-69.

Valle D, Mark S, Edson V, James G, Marcio S. 2006. Identifying bias in stand-level growth and yield estimations : a case study in Eastern Brazilian Amazonia. ForestEcolManag 236: 127-35.

Whitmore TC. 1990. Tropical rain forest dynamics and its implications for management. In: G omez-Pompa A, Whitmore TC , Hadley M, editor. Rain Foret Regeneation and Management: Man and the Biosphere Seies Vdume 6. Paris(FR): Parthenon Publishing Group. p67-89. 
Appendix 1. List of species by family in Labanan Forest

\begin{tabular}{|c|c|c|c|}
\hline Family & Family & Family & Famil y \\
\hline Adinidiacea & Dilleniacme & Maraceae & Saxifracacae \\
\hline Alangacme & Dipterocarpacae & Mynisticacae & Simaroubaceae \\
\hline Ammaceae & Ebenaceae & Myrsinaceae & Sonneratiacae \\
\hline Anacardiacae & Elaeocarpacae & Mytacae & Steruliacare \\
\hline Anmonaceae & Euphorbiaceae & Odhmacere & Symplocaceae \\
\hline A poynacme & Fagacme & Olacacae & Thercae \\
\hline Aquifdiacae & Flacaurtiacme & Olencare & Thymdaeaceate \\
\hline Araucaniaceate & Clusiacme & Oxalidacae & Tiliacme \\
\hline Bignoniacme & Hypericacea & Pdygalaceae & Ulmaceate \\
\hline Bambacaceae & Icacinacae & Proterceae & Urticaceae \\
\hline Burseaceae & Jugandaceae & Rhammacme & Vejenacae \\
\hline Cacsalpiniacae & Lauracae & Rhizqpharacae & \\
\hline Cdastracae & Leythidacae & Rosacae & \\
\hline Chrysdbalanaceae & Fabacane & Rubiace & \\
\hline Combetacme & Loganiacae & Rutacare & \\
\hline Connarace & Lythracea & Sapindacæe & \\
\hline Convdvilaceae & Magndiacæe & Saptacme & \\
\hline Crypternicae & Mdastmatacme & Sapuidacæe & \\
\hline Datiscaceme & Mdiacme & Sarcothea & \\
\hline
\end{tabular}


Appendix 2. List of Dipterocarps species

\begin{tabular}{|c|c|c|c|}
\hline No & Species & No & Species \\
\hline 1 & Anisqptera costata & 47 & Shreat bentangenensis \\
\hline 2 & Anisqtera laeis & 48 & Shorea confusa \\
\hline 3 & Anisqtera sp & 49 & Sharea exdliptica \\
\hline 4 & Cotylddaiummdanoxylon & 50 & Sharea fagudiana \\
\hline 5 & Cotylddaiumsp & 51 & Sharea faldifercides \\
\hline 6 & Dipterocarpus aatangulus & 52 & Shorea fallax \\
\hline 7 & Dipterocarpus caudifenus & 53 & Shrea giiso \\
\hline 8 & Dipterocarpus confetus & 54 & Shrea hopifdia \\
\hline 9 & Dipterocarpus confomis & 55 & Shorea inappendiaulata \\
\hline 10 & Dipterocarpus costulatus & 56 & Shoreajohorensis \\
\hline 11 & Dipterocarpus dongatus & 57 & Shore laevis \\
\hline 12 & Dipterocarpus fusifomis & 58 & Shorea lamellata \\
\hline 13 & Dipterocarpus gabrigemmatus & 59 & Shorea leprosula \\
\hline 14 & Dipterocarpus gaalis & 60 & Shorea leptodama \\
\hline 15 & Dipterocarpus gandiflonus & 61 & Sharea longisperma \\
\hline 16 & Dipterocarpus hassdtii & 62 & Shorea macrophyla \\
\hline 17 & Diptenocarpus humeratus & 63 & Shorea macroptera \\
\hline 18 & Dipterocarpus mmndss & 64 & Shrea maxudliana \\
\hline 19 & Dipterocarpus padyphyllus & 65 & Shrea meistgpteyx \\
\hline 20 & Dipterocarpus palembanica & 66 & Shrea miltiflora \\
\hline 21 & Dipterocarpus stellatus & 67 & Shorea ohracea \\
\hline 22 & Dipterocarpus tempehes & 68 & Shorea ovalisssp ovalis \\
\hline 23 & Dipterocappus vemucosus & 69 & Sharea parvifdia \\
\hline 24 & Dipterocapussp & 70 & Shrea parvistipulata \\
\hline 25 & Drydbalanops beccanii & 71 & Shrea patciensis \\
\hline 26 & Drydbalanops lancedlata & 72 & Sharea paudiflara \\
\hline 27 & Drydbalanopssp & 73 & Shorea pinanga \\
\hline 28 & Hopea bracteata & 74 & Shorea scrobiailata \\
\hline 29 & Hopea cemua & 75 & Shorea semiameta \\
\hline 30 & Hopea drydbalanides & 76 & Shorea seminis \\
\hline 31 & Hopea fenuginet & 77 & Shorea smithiama \\
\hline 32 & Hopea mengarawan & 78 & Shorea superba \\
\hline 33 & Hopea nevosa & 79 & Sharea syminganii \\
\hline 34 & Hopea padycarpa & 80 & Shorea virescens \\
\hline 35 & Hopea nudfomis & 81 & Shorea xanthophyla \\
\hline 36 & Hopea sangal & 82 & Shrea sp \\
\hline 37 & Hopea semianeata & 83 & Vatica alliramis \\
\hline 38 & Hopeasp & 84 & Vatica micantha \\
\hline 39 & Parashcrea malaanonan & 85 & Vatica nitens \\
\hline 40 & Parashorea smythiesii & 86 & Vatica ddongfolia \\
\hline 41 & Parashorea sp & 87 & Vatica obbrata \\
\hline 42 & Shorea aggmi ssp agamii & 88 & Vatica rassak \\
\hline 43 & Shrea almon & 89 & Vatica sarawakensis \\
\hline 44 & Sharea angustifdia & 90 & Vatica unbonata \\
\hline 45 & Sharea atrinervosa & 91 & Vatica vinosa \\
\hline 46 & Sharea beccariana & 92 & Vatica sp \\
\hline
\end{tabular}

